DIGITAL COMMONS
@ UNIVERSITY OF SOUTH FLORIDA

Volume 11

Issue 1 Summer 2021

\section{ABO: Interactive Journal for Women in the Arts, 1640-1830}

2021

\title{
Feminist Scholarly Communities Have Been a Lifeline During the Pandemic
}

\author{
Karen Griscom \\ Indiana University of Pennsylvania, karen.griscom@gmail.com
}

Follow this and additional works at: https://digitalcommons.usf.edu/abo

Part of the Dramatic Literature, Criticism and Theory Commons, Educational Methods Commons, Feminist, Gender, and Sexuality Studies Commons, and the Literature in English, British Isles Commons

\section{Recommended Citation}

Griscom, Karen (2021) "Feminist Scholarly Communities Have Been a Lifeline During the Pandemic," $A B O$ : Interactive Journal for Women in the Arts, 1640-1830: Vol.11: Iss.1, Article 12.

http://doi.org/10.5038/2157-7129.11.1.1268

Available at: https://digitalcommons.usf.edu/abo/vol11/iss1/12

This Conversation is brought to you for free and open access by Digital Commons @ University of South Florida. It has been accepted for inclusion in ABO: Interactive Journal for Women in the Arts, 1640-1830 by an authorized administrator of Digital Commons @ University of South Florida. For more information, please contact digitalcommons@usf.edu. 


\title{
Feminist Scholarly Communities Have Been a Lifeline During the Pandemic
}

\begin{abstract}
I teach writing and literature at a community college, and I am a third-year Ph.D. candidate. Because I balance full-time teaching and graduate research, I am accustomed to the intensity of a heavy workload. Still, during this past year, my home and work responsibilities have multiplied and with that so has my anxiety. Stress and lack of time have made it challenging to write and research. However, two feminist organizations have helped me cope and remain hopeful about my scholarship.
\end{abstract}

\section{Keywords}

Reflection, Pandemic, Writing

Creative Commons License

(c) (1) (9)

This work is licensed under a Creative Commons Attribution-Noncommercial 4.0 License 
I am glad for this invitation to reflect on how the pandemic has had an impact on my writing and scholarship. As I began this reflection, I was surprised by the many emotions that surfaced as I remember the pandemic's first weeks. In the early days of the stay-at-home order, one of my coping strategies was a regular self-reminder of how lucky I am to work from home. A stable job with health insurance and the ability to work from home are not advantages most of my students enjoy, nor are they benefits many people enjoy. I teach writing and literature at a community college, and I am a third-year Ph.D. candidate. Because I balance full-time teaching and graduate research, I am accustomed to the intensity of a heavy workload. Still, during this past year, my home and work responsibilities have multiplied and with that so has my anxiety. Stress and lack of time have made it challenging to write and research; however, two feminist organizations have helped me cope and remain hopeful about my scholarship.

When my state's governor asked people to stay home, I scrambled to figure out how to manage regular daily tasks, like many people. This work consumed a lot of the time I might have spent reading and writing. I recall how panicked I felt to find masks and gloves, figure out grocery delivery, and get supplies to my mother-in-law, who lives ten minutes away but across the state line. By May, I was managing grocery orders and deliveries, prescription pick-ups, haircuts, and technology issues. When my spouse became ill in November, I was pushed to my limit for stress. Covid restrictions at the hospital prohibited me from visiting, and my family could do little to help me. I felt very isolated and discouraged. At the same time, I was struggling to support my students.

Balancing teaching with scholarship requires careful planning and disciplined time management, but the quick move to online teaching quashed a lot of my preparation. The time I usually spent on research was devoured by adjusting schedules and modifying activities to shift to distance learning. My time was also consumed by creating instructional material to support students, several of whom were encountering online learning for the first time. For many community college students, limited time management and study skills make college work challenging under the best circumstances. Last spring, well-prepared students wrote me to ask for extensions because they were struggling to help small children navigate online learning or because they were working double-shifts as first responders. Poorly-prepared students began to disappear. In addition to reminders about assignments, my course announcements last year included links to the local food banks, Covid-19 testing centers, and mental health resources. I posted pep-talks and reminders that they were near the finish line. Encouraging my students was the easy part of my job last year; the hard part was finding the time to teach effectively with the increased institutional pressures. One week 
before the fall term began, my college's administration decided to mitigate the financial impact of low enrollment by raising the caps for classes and combining course sections. Enrollment in the five classes I teach increased by one-third. Twelve-hour days were standard last fall, so I had little time for writing.

Amid these many challenges, two organizations have helped me complete some writing and remain optimistic about my scholarship. Last spring, I discovered a series of monthly seminars hosted by the Women's Studies Group 1558-1837 (WSG). Typically held on the third Saturday of the month, these meetings feature three twenty-minute paper presentations followed by discussion. Before the pandemic, the group met at the Foundling Museum in London but has since met via Zoom, something I am very grateful for. These seminars have helped me feel a lot less isolated and have nourished my own work. Last summer's \#WriteWithAphra group made a tangible positive impact on my research and writing. Like the WSG's seminars, the weekly meetings comforted me during the isolation of the pandemic restrictions, but more than this, the \#WriteWithAphra group motivated me to write every day. Because I only teach one course during the summer, I have more time to write. Nevertheless, I am not sure I would have accomplished as much as I did without the group. I completed two abstracts and a conference-length paper, and I revised another paper. I could not have imagined how supportive this experience would be. \#WriteWithAphra was one of the bright spots of 2020. Thank you. 